\title{
Study On Decorative Art in Architecture
}

\author{
Xiao-Xia YE \\ Chongqing Vocational Institute of Engineering
}

KEYWORDS:Architecture;Interior decoration art;Design integration and innovation

\begin{abstract}
Under the background of rapid development of real estate market in China,decorative art in architecture becomes more important, and more and more buyers pay more attention to the room style and decorative art design, so how to make the interior decoration design of inheritance and innovation become important problem in building decoration. This paper studied on the decorative art in architecture, an important role,design principles and characteristics of decorative art in architecture, and how to finish innovation on this aspect.

In China, economic development has led to the prosperity of the real estate industry which indirectly led to the development of the construction industry and innovation, and people's living standard and aesthetic standards led to the prosperity of the interior design profession. Because interior decoration design inspiration must come from social practice, so how to innovate the cultural development of architectural decorative art is necessary to ensure the success of the art according to our country's unique social and historical. The connotation and important function of architectural decoration art are introduced in the followings.
\end{abstract}

\section{Connotation and important role of}

With the understanding of the connotation and its important role in the development of the society, people's life of decorative art so that we can find the direction and path of innovation on architectural art. The following introduces connotation and important function of architectural decoration art.

\subsection{The meaning of interior decoration design}

Decoration design on an object, its aim is to make people get a better aesthetic feeling, and interior design is a reasonable division of the space based on limited interior space making sure that the interior overall style and furnishings to be better meeting the aesthetic needs of the people, and the use requirements of people. Thus, architectural decoration design not only includes interior space division design, but also indoor furniture display and design of decorative items, so that the internal environment of the building to achieve the unity of aesthetic level and style.

\subsection{The importance of building decoration design}

Commentary from the practical aspect, for interior decoration design can make people's life and work space more fully and efficient used, to ensure that people feel more comfortable and convenient, without the wrong structure that affect the work and life. From the view of aesthetic and decorative design for building, it can satisfy people's psychological enjoyment needs, orderly and harmonious tone interior decoration style can make people feel happy. From the point of view of the development of art, interior design as a branch of the development of art, it riches the development of the art industry and the connotation creating more beautiful possibilities. ${ }^{[1]}$

\section{Elements and design principles of decoration design in construction industry}

In the process of interior design, it must use appropriately design elements, following the design principles in order to create good works. The following introduces elements and design principles of building decoration design.

Firstly, Elements of architectural decoration. The elements include space design, color, light ,as 
well as the characteristics of the decoration and so on, these elements will have important impact on the entire interior environment.

Firstly, as the basis for the design of the premise and the space elements. The decoration of the building design must be based on the limited interior space, so how to design a reasonable division of space and decoration placed foundation is the beginning of all design, whether interior spatial area be reasonably divided can achieve coexistence of space division practical, aesthetic and economic, which is the base of the design preference and economic capacity of the user. Therefore, the space division needs to take full account of the aesthetic requirements and customer's needs, so that the space design can convey the user's wants to show the image of the individual and the environment.

Secondly, color elements can stimulate people's senses, gorgeous color contributes to a combination of numerous possible and numerous kinds of visual effects, a little color can affect the overall of the decoration design, so color also occupies an important position, different color collocations can express different emotional atmospheres, so in the decoration of the building design, it often needs to pay attention to the coordination of color collocation, users facing different color environment can have different aesthetic feelings, such as cold tone will bring feeling of severe cold, and warm tone is the representative of lively and warm feeling, with different color collocation people can adjust the psychological feeling and aesthetic feeling. The use of color in the process of design elements should understand knowledge on color collocation, followed by the use of color collocation knowledge based on the aesthetic needs of the interior design aesthetic and sense of harmony, in the basic of color, it comply with collocation rules of bold innovation that can make the design with more characteristics and identification, letting the building decoration design industry has more directions on development.

Thirdly, elements of nature of the interior decoration means interior design must use a certain number of different decorative component which have different material, shape, styles and so on, its own characteristics in the design also plays an important role. So in the decoration component selection and placement, it must be considered in the overall design style, the decoration of the building selection in different regions when the local climatic characteristics and traditional style, decorative elements once installed to replace the purchase which will give users' economic losses, so it should do the preliminary design, And evaluate the most appropriate suggestions for the design.

The last is to improve the living comfort which is the elements of green, interior decoration design should not only consider the aesthetic feeling and economic practicability, but also the user's comfort, interior green design has become an important part of interior decoration design, improving the quality of life of the user and it also affect the overall interior environment design. To carry out interior green design must pay attention to grasp the degree of green design, it not only to play the role of the reinforced design aesthetic landscape plants, but also clean up the user's life and working environment, to bring users better use of space experience and life health. ${ }^{[2]}$

The above four design elements are indispensable for the architectural design part, so the interior design should plan the four elements to consider, and in every part of the design, it should be fully taken into account the user's aesthetic needs and economic affordability, so let building decoration design services to people's life and work.

Secondly, the basic principles must be followed in building decoration design. The rules can make sure the development direction of things to prevent things go wrong standard, so the decoration of the building design must also follow certain principles and rational use of design elements. 
Firstly, to provide design services to customer needs as an important standard, interior designer decoration design should fully consider the user's requirements and spiritual requirements of the environment. It should give full consideration to the user's requirements and living standards for the indoor environment division and their opinions and suggestions in the space division and each part of the partition ratio, which can bring a better use for consumers feeling. It also should consult what users want to express about personal feelings and personal style, and according to different requirements to determine the style of interior color collocation and artistic effect, which can make the space style as a side of user's personal spiritual expression, meeting the spiritual needs of consumers and aesthetic level.

Secondly, the interior design should take into account the level of building technology development. Rich imagination and creativity to inject more vitality and innovation for the interior decoration design, but artistic imagination should also take into account the level of development of social practice, which should give full consideration to the plan feasibility and implementation difficulty of design before, otherwise it will give the late implementation the difficulty of construction, bring more economic burden to the environment of the user which should be avoided. Designers should also pay attention to the new development of the construction industry on materials and style, according to the user's own economic conditions to choose the appropriate use of the latest technology to enhance the satisfaction.

Finally, consider the local architectural style and national characteristics. Interior design also follows local conditions, due to the influence of building the local environment of religion and culture will have different style, so the decoration of the building design should take into account the local customs and national habits. ${ }^{[3]}$

The architectural design also need to follow the basic design principles to get good design works, so the building decoration design industry's innovation also on this basis.

\section{Analysis on the innovation measures of decoration design in the construction industry}

With innovation, An industry can get more long-term development, and it should use appropriate innovative for architectural design industry after inherit selectively. The following is the analysis of innovation measures of interior design industry .

\subsection{The protection of regional architectural features and traditions}

The source of architectural design innovation comes from long history of development where the building is located, and the trend of innovation in recent years on building decoration is from the ancient architectural inspiration of retro innovation, but it can not completely copy without improvement, but should absorb essence of ancient buildings with modern technology innovation, ancient architectural decoration can spread so far and become the representative of a region of the decoration must have its special merits, so learn from the unique characteristics of the local architectural decoration design can enhance the user's satisfaction, at the same time, it can ensure that traditional architectural decoration of timeless heritage efforts not go to lose.

\subsection{Draw lessons from domestic and foreign advanced design concepts}

Some domestic architectural decoration designers lack the spirit of innovation, facing the impact of the new concept having no ability to accept, which often because of the concept of practical experience and few dare to adopt. This idea greatly content with staying where one is imprisoned the development road of architectural design industry, only to absorb the ideas and concepts to make interior design have new collision sparks, which can create new innovative ideas in the process of practice, while some designers boldly practice naturally can not let his design works appearing more innovative flash points. Learning from the advanced design concept to the designer of the development direction and development trend of international design style, trend of the 
design industry and apply it to their own design to make the domestic architectural decoration design more full of vitality and innovation.

\section{CONCLUSION}

The basic understanding of the architectural decoration industry will be the base of innovation in the construction industry, interior design also needs to use the basic elements of design, follow the basic principles of design, and interior design industry should also be in the design practice step by step to draw own advantages and disadvantages, paying attention to the shortcomings in the design and improvement of cumulative on the design of admiration in the design works one after another, and continuous innovation in practice can promote the development of our country's building decoration design, enhance the user's comfort and meet the aesthetic needs of consumer.

\section{Reference:}

[1] Wang Yingying. Research on decorative art in architecture [J]. forum, 2014 (11)

[2] Lin Qing. The application of decorative art in modern style interior design [J]. art design, 2013 (06)

[3] Jiang Chunyun et al. The style design of interior decoration design [J].2007 (02) 